G

COUNTERFUTURES

Left thought \& practice Aotearoa 


\title{
On the Unbearable Lightness of John Key
}

\author{
Warwick Tie
}

HE NEOLIBERAL REFORMS of the 1980s produced, going into the new millennium, a contradiction within capitalism that is illuminated by the unprecedented popularity of John Key as Prime Minister. As highlighted by Italian Marxist Maurizio Lazzarato, this contradiction concerns an impasse in political economy that develops as a consequence of capital's inability to create experiences of self - subjectivities - required for its own reproduction. ${ }^{1}$ In short, the contradiction signals a crisis in the social reproduction of capital, a crisis in the reproduction of capitalist subjectivity. The requirement upon people to become

1 Maurizio Lazzarato, Signs and Machines, Los Angeles 2014. 
'entrepreneurs of the self' or units of self-actuating 'human capital' produces insufficiently coherent experiences of selfhood, accompanied by a widespread development of compensatory states of narcissistic grandiosity. ${ }^{2}$ Different social formations produce particular kinds of subjectivity, and come to privilege specific public figures as ideals of the psychological traits favourable to the efficient operation of the prevailing social order. That order, in our case, is neoliberal capital of an increasingly authoritarian populist kind, and Key exemplifies its ideal subject. Resistance to the logics by which a given social order is functioning turns, in part, upon the dislocation of its central figures. Against the individualistic contentedness projected by the figure of Key, a need arises to imagine how a collective, cooperative, subject might form anew in this situation. This essay will move towards Jodi Dean's discussion of the party form to think through what such a project might entail. ${ }^{3}$

The figure of Key emerges as both a symptom of capitalism's crisis of social reproduction and, via the internal contradictions of that figure, a pathway beyond the predicament. With regard to Key being a symptom of the situation, the 'mass personification' of institutional politics, as initially identified by Perry Anderson with respect to Berlusconi in Italy, ${ }^{4}$ provides insight into the function his persona plays for contemporary capital. The mass personification of which Anderson speaks refers to the reduction, through the mediatised character of contemporary public communication, of political competence to demonstrations

2 See Christopher Lasch, The Culture of Narcissism, New York 1979; Lynne Layton, Grandiosity, neoliberalism, and neoconservatism, Psychoanalytic Inquiry: A Topical Journal for Medical Health Professionals, 34/5, 2014; Martjin Konings, (2014) Financial affect, Distinktion: Scandinavian Journal of Social Theory, 15/5, 2014; Slavoj Žižek 'Pathological Narcissus as a socially mandated form of subjectivity, accessed May 4 2016, http://mariborchan.si/text/articles/slavoj-zizek/pathological-narcissus-asa-socially-mandatory-form-of subjectivity.

3 Jodi Dean, Crowds and Party, London and New York 2016. Henceforward CP.

4 Perry Anderson, The Italian disaster, London Review of Books, 36/10, 2014. 
of personality via the production of video-blogs, publicity stunts, biographies, and the like. This reduction of politics to the banal psychologism of personality enables the figure of Key to function as a 'Mr Kiwi Everybloke' who melds with chameleon-like ability into each and every situation in which he is inserted, ${ }^{5}$ providing the perfect 'antidote to the climate of crisis' ${ }^{6}$ - and for whom the audience is less the people of Aotearoa than international finance markets $^{7}$ - the effect of which is a muting of messages by which truth could be told about the destructive effects of the policy failures associated with those reforms. ${ }^{8}$ The local mass personification of politics, as exemplified in the political leverage offered by the elasticity of 'John Key', occludes domestic recognition of any such crisis in the social reproduction of capital.

The focus of this piece falls on the second dimension of Key's appearance in this conjuncture: on the figure of Key as a site of potentially fruitful political contradiction. The kernel to that contradiction lies with the cognitive operating system that Key claims as his own and from which seemingly flows his optimistic demeanour: pragmatism. Reminiscent of the hope that a sufficient length of No. 8 wire should resolve most issues facing a settler society, pragmatism plugs into a feature of subjectivisation that left wing appeals to political principles and moral values seemingly fail to grasp. Within societies where ideas circulate primarily through the mass media, a generalised 'decline of symbolic efficiency’ has occurred, suggests Slavoj Žižek. ${ }^{9}$ Principles and values cannot be relied upon to ground thoughts and

5 Vijay Devadas \& Brett Nicholls, The meaning of John Key, New Zealand Journal of Media Studies, 13/2, 2012, p. 21.

6 Ibid., p. 23.

7 John Key and the Spirit of His Times, Political Organisation Aotearoa http://poa. org.nz/John\%20Key\%20and\%20the\%20Spirit\%20of\%20his\%20Times.pdf.

8 Campbell Jones, John Key the biofinancial entrepreneur, Kōtuitui New Zealand Journal of Social Sciences Online, 11/2, 2016.

9 Slavoj Žižek, cited in $C P$, p. 21. 
actions. As a consequence of this decrease in the gravitational pull of big ideas, people's senses of self increasingly form through the affective, rather than cognitive, proprieties of language. ${ }^{10} \mathrm{Of}$ increasing significance for the smooth functioning of late capital, in this regard, has been a form of desire that exists for its own sake. Politics becomes, in part, a contest over the ends to which desire of that rootless kind can be put. In the minds of Deleuze and Guatarri, such an experience of desire has migrated in from the outer reaches of psychical life to become "part of the infrastructure' of capital itself. ${ }^{11}$ One specific form of this desire shall hold our attention below, as it emerges from within the pragmatism of Key: a state of simultaneous belief and non-belief towards ideas, principles, and values (a state of 'disavowal').

It remains an open question as to whether the optimism conveyed by the pragmatism of Key will suffice to meet the challenge of an increasingly indebted middle class. ${ }^{12}$ Neither is it clear if and when his pragmatism will begin to rub salt into the wounds of those whose capacities to 'get ahead' are being incrementally moved to a minority investor class, ${ }^{13}$ or of those who recognise the erosion underway of the institutions central to their democratic freedoms, of law and the public service. ${ }^{14}$

What can be mapped, however, is the apparent extension of the crisis to the production of subjectivities on the Left, whether of radical or progressive kinds. Neither the subject positions associated with vanguard politics nor the proliferation of causes under the banners of nationalist populism, environmentalism or

10 Gilles Deleuze \& Félix Guattari, Anti-Oedipus, Athlone 1984. Henceforward A-O.

11 Felix Guattari, cited in Lazzarato, Signs and Machines, p. 7.

12 Between the early 1990s to the present, for example, ratios of household debt relative to nominal disposable income have risen from $58 \%$ to over $160 \%$. See 'Household debt', Reserve Bank of New Zealand, accessed January 14 2016, http://www. rbnz.govt.nz/statistics/ key_graphs/household_debt/.

13 Max Rashbrooke, Wealth and New Zealand, Wellington 2015.

14 Margaret Wilson, The Struggle for Sovereignty, Wellington 2015. 
of identity politics, resolve that crisis. Neither of these forms of subjectivity show themselves able to inaugurate a break within the prevailing patterns of socio-economic causality; nor can they seemingly envisage how, out of any such break, future possible alternatives might be crafted.

It is to the possibility of alternative subjectivities and their production that we turn. Our starting point for this exercise is the pragmatism for which the figure of Key has become synonymous.

\section{The Practitioner of Pragmatism}

Pragmatist thought has long viewed the world of ideas as running askew to the rationality by which logic is often assumed to operate. 'Every new concept first comes to mind in a judgment', Charles Saunders Peirce noted emblematically in this regard. ${ }^{15}$ Contextualising the agnosticism which pragmatic thought displays towards rationality, the work of Deleuze and Guattari suggests that pragmatism belongs to the world of 'desiring-machines': to a mode of production in which 'everything functions at the same time, but amid hiatuses and ruptures ... within a sum that never succeeds in bringing its various parts together so as to form a whole'. ${ }^{16}$ In the absence of knowable end points (the 'sum'), this concept suggests, desire forms towards projects and programmes that assume the existence of such points without ever having to claim direct knowledge. Desire comes to function at the level of 'what works'.

15 Charles Saunders Peirce, Collected Papers of Charles Sanders Peirce, Volumes V and VI, Pragmatism and Pragmaticism and Scientific Metaphysics, Cambridge MA 1934, p. 385.

16 A-O, p. 42. 
Ironically, as Deleuze and Guattari note, the networks of projects and plans that comprise desiring-machines function not by fulfilling the grand intentions inferred of them but, rather, through their state of continually breaking down: 'That is because the breaks in the process are productive, and are reassemblies in and of themselves'. ${ }^{17}$ The fact that a given project might head off in a new direction as a consequence of its interruption by a programme of a different kind merely attests to the productivity of contemporary production. As Lazzarato adds, an associated stripping of desire from idealised outcomes produces a mode of political calculation no longer capable of exercising critical concern toward the material reality in which calculation itself functions. Instead, planning becomes that 'of the possible, of the creation of new potentialities, of the emergence of what appears possible within the framework of capitalist domination'. ${ }^{18}$

'I've always been a glass half-full as opposed to a glass half-empty', Key has remarked in a gesture towards this productive state of incompleteness, 'and the day that changes is the day I should leave'. ${ }^{19}$ Politics would have no allure, this clichéladen statement suggests, if desire were to adopt more than an agnostic stance toward the material totality ('the sum') in which it operates. Of greater significance, then, than the big ideas and visions in which political thought might engage individuals in the consummation of their desires, is pragmatism's capacity to ceaselessly produce desire unsullied by matters of substance.

Pragmatism's potential for the endless generation of desire lies with the relationship between the regulatory ideals by which political communities configure themselves (democratic equality, rule of law, and so on) and the network of behavioural

17 Ibid.,p. 42.

18 Maurizio Lazzarato, Signs and Machines, p. 51.

19 http://m.imdb.com/name/nm3658941/quotes. 
relations by which those ideals gain tractive force. Peirce, again: A quality is something capable of being completely embodied. A law never can be embodied in its character as a law except by determining a habit. A quality is how something may or might have been. A law is how an endless future must continue to be. ${ }^{20}$

The materialization of a community's regulatory ideals (like order) into concrete objects (like law) occurs only via the circuits of interaction that bind its members ('habit'). Gesturing, also, to the significance which networks of circulation play in the constitution of ideas, Key observes of his own work practices:

It's possible to spend every waking hour here on the ninth floor and not get out of the office. And this isn't the real world in here. And contrary to public opinion, I'm not incredibly poll-driven. They are an ongoing indicator of how we are going, but I take the feedback I get on the street as the most important. ${ }^{21}$

Understood through the logics of pragmatism, the empirical objects to which the concepts of 'democracy', 'law' etc. point are thereby seen not to exist 'as such'. Take the example of money:22 a pragmatist quite understands that no material equivalent exists for a coin or dollar note. They will be comfortable that the Governor of the Reserve Bank would indicate the value of their $\$ 20$ note by presenting them with another $\$ 20$ note. The pragmatist also understands, however, that the absence of intrinsic value does not stop money from producing concrete material effects as it circulates. It both 'is' and 'is not'. This same phenomenon of splitting characterises John Key's interpretation of 'economy':

I think it is only natural that people have anxiety about the economy because the economy is real. It is their job, their ability to service their mortgage and look after their family. And in the final analysis,

20 Charles Saunders Peirce, Collected Papers of Charles Saunders Peirce, p. 103.

21 http://www.brainyquote.com/quotes/authors/j/john_key_2.html.

22 See Slavoj Žižek, The Sublime Object of Ideology, London and New York 1989, pp. 18-19. Henceforward SOI. 
nothing is more important than your capacity as a breadwinner or an earner to provide for those that rely on you. ${ }^{23}$

The economy simply 'is': it is 'real'. Simultaneously, it is no one thing in particular (a job; a source of mortgage payments; a means of household consumption; the list could go on ...). Moreover, the surest sign that no substantive content underpins the range of the economy's appearances comes from the moral register (as opposed to analytic or diagnostic) in which Key delivers his concluding point: 'in the final analysis ...' there is no analysis to be had about the meaning of economy, only a shared practice of moralising talk ('nothing is more important ...') towards a point of reference merely presumed to exist. As the Scandinavian scholar of political economy, Martjin Konings, observes in general of pragmatic analyses of the 'economy':

The economy is not a discrete method or an easily wielded instrument of control, but refers to the semiotic dynamic whereby we become invested in the sign and internalize a particular relation to the unobservable. ${ }^{24}$

As recognised by the early American proponents of pragmatism, and re-emphasised in Konings' summation, the simultaneous existence and non-existence of social objects propels the subject into states of affective attachment. Perhaps unexpectedly, for the principled Left at least, the practitioners of pragmatism do not invest in the big ideas of modernity: democracy, law, expertise, and so on. The symbolic efficiency of big ideas, as noted, has been on the decline. Rather, the attachment is toward the social networks by which semblances of those ideas are designed, produced, and traded. A quotation oft-times cited from the American pragmatist William James, a contemporary of Peirce, anticipates this condition. James suggests that big ideas arrest the imagination not because of the manner in which they seemingly express

23 http://www.brainyquote.com/quotes/authors/j/john_key_2.html.

24 Martjin Konings, The Emotional Logic of Capitalism, Redwood City 2015, p. 52. 
timeless truths. Rather, their social efficiency turns upon the degree to which people invest themselves in the networks of social relationships within which those big ideas are circulating:

I am done with great things and big things, great institutions and big success, and I am for those tiny, invisible molecular moral forces that work from individual to individual, creeping through the crannies of the world like so many rootlets, or like the capillary oozing of water, yet which if you give them time, will rend the hardest monuments of man's pride.

Gone are hopes of accessing the 'big' and 'great' things of modern life ('I am done with ...') and, instead, desire emerges for participation in ('I am for ...') the circulation of the semblances by which those objects come to exist. Such is the systemic kernel of pragmatism as a desiring-machine of late capitalism. A message by Key to the public regarding the 2008 global financial recession illustrates this point:

We don't tell New Zealanders we can stop the global recession, because we can't. What we do tell them is we can use this time to transform the economy to make us stronger so that when the world starts growing again we can be running faster than other countries we compete with. ${ }^{25}$

Key's view of the economy is thereby characterised by simultaneous visions of inevitable growth ('when the world starts growing again') and recession (a recession 'we can't stop'). In the face of the deadlock between those images, the pathway of desire ('we will be running faster') is toward enhanced levels of practical participation in the existing networks of capitalist organisation ('we can use this time to transform the economy').

As a desiring-machine, pragmatism shakes the rational ground upon which critical analysis frequently announces itself. Radical criticism, as oft-times occurs in the principled names of egalitarianism, fairness, justice, and so on, is easily recoded in

25 http://m.imdb.com/name/nm3658941/quotes. 
keeping with pragmatist desire. Proponents of neoliberalism can just as easily talk of (child) poverty reduction, ${ }^{26}$ social fairness, ${ }^{27}$ justice, ${ }^{28}$ and so on. From the viewpoint of pragmatic governance, the points of principle upon which the Left might criticise neoliberal reforms are but objects that move in keeping with shifts in the language games of political contestation. As seriously as such principles need to be taken publically by those who govern, the pragmatist would also say that the state of seriousness need only be lightly held. Note the tacit qualification, in this regard, of Key's assessment as to the socio-political significance of the global fight against inequality: 'We live in a world where equality is pretty important'. ${ }^{29}$

A still greater challenge awaits radical critique, however. If it were to succeed in prompting popular criticism of neoliberalism, progressive thought would be at risk of presenting itself as being other than a desiring-machine. Emblematic here are the attempts in the last electoral campaigns of Labour and the Greens alike to present sets of well-reasoned policies, to counter the relative lack of policy detail with which National campaigned. In comparison to the seemingly open-ended capacity of pragmatism to generate raw desire in and of itself, the kinds of desire on offer from the centralist Left appear to be all too tightly prescribed (if not archaic to the ears of the contemporary New Zealanders) - these being principles of fairness, justice, equality, and so on.

A difficult political challenge thereby emerges in this situation for radical thought. It must successfully criticise the

26 See, for example, Budget will contain measures to tackle poverty New Zealand, The New Zealand Herald, May 152013.

27 See, for example, Audrey Young, Govt insists fairness at heart of Pike River compensation denial, The New Zealand Herald, November 212013.

28 See, for example, Todd McClay, NZ deeply disappointed by whaling decision, Scoop, accessed December 2 2015, http://www.scoop.co.nz/stories/PA1511/S00541/nzdeeply-disappointed-by-whaling-decision.htm.

29 http://www.brainyquote.com/quotes/authors/j/john_key.html. 
naturalness attributed to pragmatic thought while, nevertheless, co-opting the optimistic open-endedness which pragmatism projects.

The seeds for productive responses sit within that simple dialectical observation, noted earlier, that Deleuze and Guattari make of desiring-machines: such apparatuses function not by working but, rather, by 'being in a state of breaking down'. ${ }^{30}$ Each and every desiring-machine exists to the extent to which their points of internal rupture produce forms of subjectivity that can create new ways by which to experience desire. This insight suggests that it might thereby become possible to reach beyond neoliberal pragmatism through itself, to identify new forms of political subjectivity latent within its internal antagonisms.

Two associated tasks emerge in this process of critique: the identification of points at which the desiring-machine of pragmatism is presently breaking down; and the redirection of those forces toward collective ends. As with the novel by Milan Kundera from which this paper borrows its title, ${ }^{31}$ a pivotal question becomes how a subjectivity oriented toward the pursuit of seemingly ceaseless multiplicity (in politics, as in sexual relations) might morph through the internal dislocation of its own practices of thought, into experiences of the self that expand in relation to the world held in common.

\section{Pragmatism as the Practice of Disavowal}

Characteristic of the pragmatism of neoliberal governance is the apparent inability of its subjects to acknowledge the constitutive role played within their thought by the psychodynamic phenomenon of disavowal. Disavowal is the Freudian term for a state of

30 A-O, p. 8.

31 Milan Kundera, The Unbearable Lightness of Being, London 1984. 
simultaneous belief and non-belief. We could think of it, in vernacular terms, as our propensity to lie to ourselves.

This dynamic can be explained in terms of the psychical structure that Jacques Lacan called 'perversion'. ${ }^{32}$ Perversion does not refer, as the name might imply, to a refusal of hetero-normative sexuality (notwithstanding Lacan's use of homosexuality to illustrate the phenomenon). Rather, perversion is a discursive structure that prevents objects from gaining tractive force within the symbolic order. In the case of disavowal, that structure is a point between belief and non-belief. It is a site within, and about, which words cannot form. With regard to Key's description of 'economy', for example, the point at which he passes from stating that it 'is real' to the point in which his words demonstrate it does not exist in the manner just stated, cannot itself be expressed.

As a consequence of the perverse structure of disavowal, the phenomenon necessarily remains in a state of repression. It cannot be brought to mind. One effect of this is that decisionmaking processes that pivot upon the practice of disavowal appear as absolutely natural, as being philosophically inconsequential, if not politically neutral. 'There is nothing going on here ... move on ...'.

A particular class of object is set in motion by the operation of disavowal: fantasy. Fantasy binds human organs with thought, being the discursive mechanism by which ideas come to exert something akin to a gravitational force upon the mind. As Žižek notes, the most functional of all fantasies within the societies of late modernity is the seemingly innocuous phrase 'as if'. With regard to the operation of the capitalist economy, for example,

32 See Jacques Lacan, The Seminar. Book 1. Freud's Papers on Technique, 1953-54, Cambridge 1988, p. 221. 
individuals proceed as if the commodity is not submitted to physical, material exchanges; as if it is excluded from the natural cycle of generation and corruption; although on the level of their 'consciousness' they 'know very well' that this is not the case. ${ }^{33}$

The phrase 'as if' occupies the place of what is otherwise the impenetrable kernel of disavowal. Its use should be read as being no less than a political practice. Where an idea comes to be presented 'as if' being true, semblances of the referent to which that idea points can begin to circulate and to accrue social power.

John Key's statement on 'the economy' again exemplifies this latter set of points regarding the role of fantasy within disavowal: notwithstanding the inability of Key's description to account in any reasonable way for the existence of 'the economy', it is enough that the economy is 'as if' real for it to be talked about in the concrete terms implied by his statement ('it is real! [even though my reference to it as a list of attributes will disclose that it is anything but] ...').

The significance of fantasy extends also into the constitution of neoliberal subjectivity. The psychical instability induced by states of simultaneous belief and non-belief, by the operation of the fantasmatic 'as if', is accompanied by compensatory states of narcissism. Typifying that narcissism is a psychical condition of 'splitting'. Psychotherapist Lynne Layton describes that splitting as a persistent oscillation within people between 'grandiosity and self-deprecation'. ${ }^{34}$ Delusions of grandeur and depression become discomforting companions. Sustaining the formation of such psychical states, Layton posits, is the nuclear family as fetishized under neoliberal conditions - in which 'anxieties about class mobility' flourish amidst a persistent belief that individuals must inevitably prosper - and public policy, where 'social prob-

33 SOI, p. 18. Original emphasis.

34 Lynne Layton, Grandiosity, neoliberalism, and neoconservatism, p. 463. 
lems are reconceptualised as individual problems that market forces such as privitization and consumer products can solve'. ${ }^{35}$ Under such conditions, "paradoxical psychological states of too much responsibility (for the self) and too little (for the common good) ensue'. ${ }^{36}$ To reframe Layton's observations in the terms of the dynamics of disavowal, it is as if a (non-existent) collective end exists under neoliberal conditions, in respect of which the subject must be made personally responsible.

Subjectivity stumbles under the dislocating effects of that disavowal. Not only does this psychological fragility play out in the clinic but also in political culture. Layton observes this brittleness forming, for example, in and around the grandiosity with which her fellow Americans can perceive the place of their country in the world: "The need to be \#1 only increases when people become, at some level, aware that they are anything but \#1 - and cannot speak about that awareness'. ${ }^{37}$

In a similar vein, Konings observes that disavowal results also in a knotting of subjectivity around sets of "paradoxical strange loop(s)', ${ }^{38}$ and 'wounded attachments'. ${ }^{39}$ This is, Konings observes, 'the paradoxical way in which moderns use their reflective capacities to sustain forces that injure them' ${ }^{40}$ Emblematic of such narcissism since the 1980s has been the subject's 'anxiety-driven integration into disciplinary mechanisms of credit and debt in a context of stagnant wage growth and rising unemployment'. ${ }^{41}$ The very model of economy which depletes the subject's well-being becomes the mechanism to which the subject looks for remedy.

35 Ibid., p. 468.

36 Ibid., p. 469.

37 Ibid., 471.

38 Martjin Konings, Financial affect, p. 48.

39 Martjin Konings citing Brown 1995, in Financial affect, p. 43.

40 Konings, The Emotional Logic of Capitalism, p. 7.

41 Ibid., p. 107. 


\section{Responses to Disavowal}

A small set of subjectivities has emerged in the Left seemingly capable of challenging the socio-political effects of neoliberal disavowal. These are exemplified, on the one hand, by attachments to political principles and social values whose mere articulation is anticipated to garner commitment. On the other, attachments form to the epiphenomenal aspects of political life - such as the particularism of identities - in an apparent anticipation that the recognition of difference holds the key to progressive politics.

Viewed from the lens of Hegelian dialectics, both subject positions are but moments in an interpretive lens of 'determinate reflection'. ${ }^{42}$ The development of political subjectivities in either manner (in Hegel's terms, from the interpretive practices of 'positing reflection' and of 'external reflection'), can only progress to the extent to which those approaches also participate in the practice of disavowal. To this end, success in the act of applying political principles or values, or of refusing on the particularistic grounds of identity-politics, implies a binding of subjectivity to the same systematised state of self-deception as characterises the pragmatism of Key. The act of engaging with such standpoints more seriously than their advocates becomes the means by which disavowal may, instead, be dislodged from within progressive analysis. How so?

The use of 'positing reflection' to envision alternative economic systems and socio-political relations, as occurs through appeals to first- principles and core-values, assumes that such alternatives are readily accessible to experience. Such values or principles 'speak for themselves' as a consequence of being asserted. The National Government's assertion as to the forthcoming availability of technological fixes for climate change illustrates the phenomenon. ${ }^{43}$

42 See SOI, pp. 201-32.

43 See, for example, Oliva Wahhan, Waiting for climate change action, The Domin- 
The rhetorical force of projects produced through the practice of reflective positing does not turn, as might be anticipated, upon the strengths of their proposals for future alternatives. Such programmes of reform might indeed appear to connect the idea of principled vision with concrete planning for future states. We need only, however, consider the limited detail available on 'anticapitalist' futures, or of 'technological fixes to climate change', to realise the imaginary impulses at work here. In the absence of such detail, a subjectivity that functions through the simple assertion of ideas is liable to become enmeshed in disavowal. Such individuals are likely to believe themselves capable of speaking at length about alternative futures given the strength of their critiques of the present, but are actually only able to believe in (to never move beyond) the act of critique. ${ }^{44}$ All too often, the response to this impasse is a mounting of hysterical tirades against those who do not believe in the same way.

The pathway towards alternative subjectivities lays, for Žižek, with the act of taking seriously the deep assumptions being made in the act of asserting truths. Common to projects produced in this way is the presumption that the realm of representation exists prior to the language in which it occurs. Language is thereby assumed to simply perform a function somehow already given to it: to represent reality. Language does not simply represent reality, however. It has no given task. Myths and legends, for example, have social effects for their participants even though the stories do not correspond with the known world. Ironically, this is a point which pragmatism seemingly accepts about truthclaims. When pushed to its logical conclusion, however, this assumption indicates that all truth-claims are always already

ion Post, 30 March 2015; Bold climate change target, The Timaru Herald, 13 July 2015.

44 See also Alenka Zupančič, When Surplus Enjoyment Meets Surplus Value, in Justin Clemens and Russell Griggs, eds., Jacques Lacan and the Other Side of Enjoyment, Durham and London 2006, pp. 155-178. 
(mere) representations, that all claims about the nature of the world are inflected by a range of political and ethical commitments. At those points where Key might assert that 'the economy' is indeed 'real', the radical Left would be advised to point out that the vitality of such a foundational idea in neoliberal thought depends very much upon its ongoing ability to resonate with the deep investments of the (conservative) communities through which it circulates. There is nothing natural about it at all. To reframe the point, the radical Left needs to become even more serious about the tenets of pragmatism than the pragmatist would dare: no truth-claims whatsoever escape the mediating effects of the cultures in which they appear.

In taking seriously the central presupposition of reflective positing, analysis opens onto a state of 'external reflection'. ${ }^{45}$ We are getting closer here to the preferred terrain of leftist political thought: that there exists an ultimate good towards which collective action might struggle. External reflection acknowledges that practices of understanding are always contingent upon a diversity of socio-cultural conditions, such that interpretation is always mediated by a range of socially stratified experiences, philosophical commitments, culturally mandated authorities and so on. It acknowledges that all truth-claims are indeed mere representations. The 'externality' of this reflective mode lies with the manner in which the interpretive act thereafter assumes the existence of a point lying beyond the field of representation; that is, a point in which resides the truth of that field's interpretive fragmentation. External reflection, Žižek notes, "transposes the "essence", the "true meaning" ... [of a text/event/object] ... into the unattainable beyond, making of it a transcendent "Thing-initself". ${ }^{46}$ For the Left, the prospect of an anti-capitalist future frequently appears in this mode: it appears as a site that exists

45 SOI, pp. 224-5.

46 Ibid., p. 213. 
independently of the cultural traditions, identities, and desires within whose ambit it is being imagined. For Key, similarly, 'the economy' appears in this same way, unsullied by traditions, histories, and psychical investments. To speak of 'the economy' or 'the anti-capitalist future', in this manner, risks delusion.

As with the practice of reflective positing, the subjectivity at work in the enacting of external reflection can be moved beyond through an act of taking more seriously than its proponents the underlying presupposition of the practice. This applies to left wing critics as much as to neoliberal pragmatists. The point that is to be taken more seriously than its advocates might bear is the externalist proposition that there indeed exists something (an 'essence') beyond the field of appearances. Reality indisputably exists. Moreover, it is singular and material in form. In light of that proposition, the appearances by which the essence of an object manifests are never sufficient to express that reality. The ongoing failures of economic interventions with the Global Financial Crises - of both the fiscal kind (Keynesian-type government investment) and monetary form (austerity) - illustrate this point: although the two encompass the entire range of possible capitalist responses to the economic crisis, neither prove able to suture the sundered field, to reform 'the economy'. In the same way, the array of identity-based, ecological and peace social movements that comprise the contemporary field of counterhegemonic politics never tells us what 'the political' is. Notwithstanding hopes that they might coalesce into a 'beautiful moment' of transformative political change, ${ }^{47}$ the time of such a moment appears unimaginable.

To this proposition, the insight can be added that 'this "essence" is nothing but the inadequacy of the appearance to itself". ${ }^{48}$

47 CP, pp. 125-6.

48 SOI, p. 206. Original emphasis. 
What might this dense statement from Žižek mean? The Thing (the 'essence'; 'the economy' or 'the political' for 'example) exists in a state of internal inconsistency (split between itself as a referent and the cultural appearances it takes within specific communities). Moreover, the field of appearances by which that referent comes to exist 'amongst us' (of markets or political campaigns, for example, as a fabricated field of objects and processes by which particular groups might pursue freedoms) is also ruptured from within. Contradictions pepper that field of appearances (as between, in a low-wage economy, competing demands for people to both actively consume and to take responsibility for the debt they thereby amass). The essence is no more than the inadequacy of attempts at its representation.

A state of 'absolute negativity' thereafter envelops attempts to represent big ideas and concrete projects formed towards their realisation. ${ }^{49}$ Ideals can thereafter no longer be imagined to reside in a cocooning 'beyond' awaiting their enactment while, similarly, concrete forms cannot be imagined independently of the socio-cultural processes within which they are compromisingly situated.

A Lacanian insight becomes important at this stage so as to prevent this state of 'absolute negativity' from plunging political analysis back into the sinkholes of ambivalence and self-deception that characterise disavowal. The condition of absolute negativity does not result in subjectivity finding itself paralysed because anything that is asserted must also be denied. Rather, Lacanian analysis draws attention to the role played at such points by emergent signifiers of lack. ${ }^{50}$ These are a class of signs whose relations with reality remain so indistinct that they can sustain a number of meanings being generated out of

49 Ibid.

50 Ibid., pp. 220-4. 
them. Žižek finds in Hegel a lead for understanding their role in enabling radically transformative change. The aspirational icons by which subjectivity might ordinarily find itself motivated - of Spirit, Self, State, God and so on - successfully circulate through social spaces to the extent to which those objects are in practice inflected by

an object which, by its very inadequacy, 'gives body' to the absolute negativity of the Idea : 'the Spirit is a bone', 'Wealth is the Self', 'the State is the Monarch', 'God is Christ' .... the Spirit is the inert, dead skull, the subject's Self $i s$ this small piece metal that I am holding in my hand, the State as the rational organization of social life is the idiotic body of the Monarch, God who created the world is Jesus, this miserable individual crucified together with two robbers ... ${ }^{51}$

Ideas will not gain transformational traction, Žižek is suggesting, simply as a consequence of being seen to be 'the true nature of things' (reflective positing) or 'an unattainable ideal to which we must nevertheless aspire' (external reflection). Rather, the symbolic efficiency of transformative ideas begins in the fact that this very negativity, to attain its "being-for-itself", must embody itself again in some miserable, radically contingent corporeal leftover' ${ }^{52}$ It is by virtue of a class of banal elements that radical Left thought might begin to reconfigure the terrain of political contest. What might this mean?

Between this domain of a 'contingent leftover' and the domain of the transcendent thing-in-itself sits a dialectical impasse - what Hegel called a state of 'infinite judgment'. ${ }^{53}$ We can only access something as grand as the 'the political', for example, via campaigns and strategies limited by their respective times and places, knowing very well the impossibility of experiencing that ultimate state 'in itself' through participation in those events.

51 Ibid., pp. 206-7. Original emphasis.

52 Ibid., p. 207. Emphasis added.

53 Ibid., pp. 206-7. 
The element to emerge in that state of infinite judgment is, in Lacan's understanding, not simply another object but the subject itself. The subject is what emerges in the act of facing the impossibility posed by the gap between the set of idealised objects to which communities are given to aspire (the 'Thing-in-itself') and the field of banal artefacts by which those elements take concrete form within the social. The specific content which subjectivity might thereafter accrue will depend upon whether the state of 'infinite judgment' by which it is birthed is turned into something 'sensible' (into a productive and responsible member of society complete with career, family, mortgage and cat) - or enabled in its impulses to exceed both what it is given to dream and the reductive forms by which such dreams are presented for its consumption.

\section{New Sites of Political Subjectivisation}

In the context of a continuing state of neoliberal hegemony, one measure as to the political value of philosophical thought is the degree to which it can seed counterhegemonic ideological infrastructure. To reframe the point in the terms of the present argument, a prevailing issue concerns how political organisation might function so as to displace both the disavowal of neoliberal pragmatism and the 'positing'/'externalising' analyses of much left wing thought, so as to enable new political subjectivities to emerge. Gesturing towards the institutional form which Hegel's 'determinate reflection' might take in Aotearoa New Zealand is Jodi Dean's widely discussed work Crowds and Party ${ }^{54}$ A central tenet of her text is that radical politics needs to find a way of sustaining popular desires for social equality beyond their sporadic

54 See Dylan Taylor, The Coming of the Communist Party, New Zealand Sociology, in press; and Mind the gap, Daphne Lawless accessed June 30 2016, https://fightback. org.nz/?s=Dean. 
expression in mass protest events, in a manner which enables 'the people' to emerge as a collective and transformative subject. ${ }^{55}$

At stake is the relationship between political organization, the crowds of mass protest, and 'the people': 'We need to be a party for the people in the crowd. ${ }^{56}$ That relationship is an affective one, pivoting upon a set of psychodynamic processes of which transference is the key. ${ }^{57}$ In the terms of the present argument, it is the operation of transference around political events that becomes important here as a successor to the disavowal of neoliberal pragmatism. How might that work?

A successful radical organization is one that can project back to the protesting crowds the desires for equality that are unconsciously expressed in mass action, suggests Dean, such that participants recognize the desires as being their own. In the process of that recognition, the participants stand to see themselves as belonging to a revolutionary group. That new collective subject - 'the people' - will function as a transformational force so long as political organization remains able to provide to them a transferential screen upon which their desires are projected. ${ }^{58}$

This unusual notion of a political party as 'a transferential site' can be understood from Althusser's formulation of ideology, upon which Dean draws. Althusser famously viewed ideology as 'representing' to individuals their 'imagined relations' to the 'real conditions' of their existences. The significance of this starting point for the present analysis lies with the manner in which that formulation resonates with Hegel's determinate reflection. The subject's 'real' conditions of existence can never be directly known. Rather, what the subject can recognise easily are the cul-

$55 \quad C P$, p. 5.

56 Ibid., p. 265.

57 Ibid., pp. 183-90.

58 Ibid., p. 5. 
tural artifacts of that reality (the images, material objects, statements and so on, attributed to that reality). Ideology becomes a mechanism through which those representations are then knitted into coherent narratives such that the individual can imagine a relationship existing between themselves and those 'real conditions' of their lives. At the level of the individual, ideology thereby functions as that 'transferential screen': it reflects back to subjects what they already always desire-a dynamic relation they presume to exist with the real conditions of their lives.

Notwithstanding this starting point, Dean senses that Althusser's formulation reinserts bourgeois individuality into the communist project: the subject of Althusser's definition is, on the face of it, an individual. ${ }^{59}$ The act of rectifying this problem is central to the quest for a collective political organization that can replace the ego-centric contentedness of neoliberal thought. This apparent individualization of subjectivity in Althusser's work can be fixed simply, for Dean, through an 'inversion' of his formulation of ideology. ${ }^{60}$ The subject is always already 'collective', an unruly condition that stands ready to be released from a state of being 'enclosed in [the bourgeois idea of] the individual'. ${ }^{61}$

In her analysis as to how the party might perform its difficult role of being a 'transferential site' for the desires of the crowd, Dean makes much of the practices that had characterized the local meetings of the twentieth century American and British communist parties: reporting on actions undertaken, sharing new information, preparing written material and so on. Of most significance, in this regard, were the 'trials' through which

59 At best, Dean's position on Althusser is partial given that the text 'Ideology and ideological state apparatuses' overtly subverts any reading conducted from the subject-position of a coherent ego. Althusser appears to have been well aware of the problem Dean outlines.

60 Ibid, p. 74.

61 Ibid., p. 87. 
errant Party members were confronted with their actions. Such events crystalised the organisational issues associated with the corralling of unruly political desire. They were not without, as a consequence, their excesses: ${ }^{62}$

The trial exposes the gap of desire as perhaps no other element of Party infrastructure can. Desire is never desire for a specific obtainable object- desire cannot be satisfied. Lacan's famous dictum is that "desire is the desire of the Other." Desire opens up as a gap in the Other, as what the Other lacks. At times desire can become so overwhelming that it becomes concentrated in a singular place, such as a person imagined as a unified individual. The gap is filled in, the dream of justice truncated and distorted. Misdirected, thwarted back in on itself, desire becomes obscene. ${ }^{63}$

The value of such practices, notwithstanding the apparent excesses with which they could be exercised, lay with how the discipline of the party came to be internalized by members, such that the boundary line blurred between subjectivity and party and the organization became the internalized dispositions of its members. Dean makes this point through the recounting of one comrade's perspective on the unpopular task of selling the Communist newspaper:

because if I didn't do it, I couldn't face my comrades the next day .... They say to us, 'The Communist Party held a whip over you.' They don't understand. The whip was inside each of us, we held it over ourselves, not each other. ${ }^{64}$

To be sure, Dean says, the exercise of Party authority can result in excesses that injure members. This is a risk, however, that must be accepted:

The actuality of the Communist Party exceeds its errors and betrayals. It encompasses the hopes for justice and aspirations for equality invested in it. To reduce the Party to its excesses fails to

62 Ibid., pp. 243-8.

63 Ibid., p. 247.

64 Ibid., p. 234. 
recognize its indispensable capacity to generate practical optimism and collective strength. ${ }^{65}$

For those who support the rehabilitation of the party form, yet who sense in such a situation proto-religious processes akin to brainwashing, a difficult issue emerges. ${ }^{66}$ In Althusser's terms, the issue becomes one of how knowledge held in the party about the 'state of affairs' might avoid the emergence of strong positions whose doctrinaire form must be somehow simultaneously rejected, in order for that transferential relation between the party and 'the people' to remain. This matter concerns the psychodynamic processes by which knowledge functions within political organisation. In the language of Lacan, the matter is one of sustaining the party in a state of being a 'subject supposed to know' rather than one that believes itself to know. ${ }^{67}$ In the terms of determinate reflection, again, the task becomes that of sustaining the party's knowledge in a state of 'absolute negativity' with regard to both people's real conditions and the understanding those individuals hold of their lives. The party cannot be allowed to believe itself to know.

The significance of this matter is signaled in part when Dean muses on Lenin's question as to what is to be done. 'Too much', is the reply; 'the answer is always too much'. ${ }^{68}$ The state of excess need not simply mean here that there are always too many tasks for the bodies available. It can also mean that the situations within which tasks need be undertaken are always in a state of change.

65 Ibid., p. 247.

66 See, for example, Daphne Lawless, Mind the gap.

$67 C P$, p. 187. The term subject-supposed-to-know was used by Lacan to describe the epistemological status of the analyst in the clinical setting. The analyst must be presumed by the one undertaking analysis, to 'know'. Of course, the analyst can never have the knowledge of their client that is presumed of them. That state of knowing is simply, in functional terms, a fiction that is required in order for transference between client and analyst to begin.

68 Ibid., p. 239. 
A further set of observations from Dean about the practices of those earlier communist gatherings becomes important here for understanding how the party form might avoid the temptation to exert mastery. The practice that Dean highlights is one of collective analysis. Local meetings would frequently begin with members contributing from their various experiences to updates on current local and global events. This would function 'like a conversation among neighbors over a common problem. Anyone can speak. Underneath the informality, a deeper structure unfolds. Speakers describe the world situation ...' ${ }^{69}$ Such discussions would then frame the terms upon which the subsequent business of meetings would be conducted.

The meeting connected the local, the immediate, with world-historical events .... Comrades drew strength from seeing themselves in a larger setting .... The particular was a bog .... Meetings broadened lives by opening them to the political, attaching them to movements and tendencies that took them out of miserable isolation. The world didn't simply happen to them. They fought to shape the world. ${ }^{70}$

This simple act of iterative analysis had the effect of sustaining the groups in a state of openness to the real and evolving conditions of their memberships. Each person thereby stood to see themselves in the course of the struggle against the prevailing logics of capitalist necessity. Rather than these members being subsumed by the party's state of knowledge, they would each find themselves expanding into the experiences and insights of others. Subjectivity would thereby become collective in a manner that had the potential to avoid the collapse of collectivity back into the singularity of a vanguard mentality. Rather, each individual stood to enter a state of experiencing themselves as part of history's 'many'.

69 Ibid., p. 243.

70 Ibid., p. 226. 
In the language of Deleuze, political organisation that functions through practices of reiterative materialist analysis of determinate reflection in other words - has the potential to produce desire without presuming knowledge of the object in respect of which desire should function: the History which groups would recurrently narrate is one of their own making. The party form, as predicated upon such practices, can thereby succeed neoliberal pragmatism as the dominant political desiring-machine.

\section{The Situation Revisited}

A contradiction emerges in capitalism as a legacy of neoliberal reforms, for which the figure of John Key is a symptom: a crisis in the production of subjectivities capable of reproducing the logics of capital. Not only is Key a symptom of that crisis. Contradictions within the cognitive machinery by which his political thought functions - pragmatism - also provide a platform for the production of new subjectivities. These are subjectivities capable of moving Aotearoa New Zealand beyond neoliberalism, as the prevailing hegemon increasingly exhibits traits of authoritarian populism. That shift involves a substitution of 'desiringmachines': from the systematised self-deception of neoliberal pragmatism ('disavowal') to a kind of political analysis that can repeatedly form anew in the process of its use ('determinate reflection'). Demonstrating how determinate reflection might produce political subjectivities capable of doing so and of keeping at bay the cossetting lure of disavowal - as reminiscent of the figure of Key - is the resurgent communist party form, an organisation offering a means (a 'transferential screen') by which participants in the crowds of mass protest might see their desires for equality projected. The central challenge of the party form is not, as might be anticipated in some quarters of the Left, to have it express the diversity of desires unleashed in mass protest. This would invoke 
either the logic of reflective positing - and uncritical assertions as to the authenticity of those desires - or external reflection and its disavowal of the singularity of the social's real conditions. Rather, the core challenge for the party as political project is of how it might remain open to those real conditions in their changing form, such that those who are drawn thus come to experience themselves as constitutive of that transformation.

\section{Acknowledgements}

I wish to thank Bruce Edman and Anna Fielder for their comments on an early draft of this paper, and to the reviewers whose further input helped develop my understanding. 
If you like what you have read, please subscribe or donate.

\author{
G \\ COUNTERF UTURES \\ Left thought \& practice Aotearoa \\ (C) Copyright Counterfutures 2016
}

